\title{
Procedural \& Distributive Justice and Amenability to Psychological Treatment in Juvenile Delinquents
}

\author{
Martha Frías-Armenta, Amelia E. López-Escobar, Graciela Jasa Silveira \\ Department of Law, University of Sonora, Hermosillo, Mexico \\ Email: marthafrias@sociales.uson.mx
}

Received 19 November 2015; accepted 13 February 2016; published 16 February 2016

Copyright (C) 2016 by authors and Scientific Research Publishing Inc.

This work is licensed under the Creative Commons Attribution International License (CC BY). http://creativecommons.org/licenses/by/4.0/

(c) (i) Open Access

\begin{abstract}
This study was aimed at testing a structural model that analyzed the relationship between procedural and distributive justice and the amenability of psychological treatment for juvenile delinquents. Ninety-two adolescents receiving treatment in detention and community facilities following a judge's sentence constituted the sample. Participants responded to a questionnaire including items that investigated the perception of police and judicial procedures and decisions, and the acceptance of psychological treatments. A structural equation model was specified and tested. Three factors were indicated "perception of police treatment", "procedural justice", "distributive justice", and "amenability of the treatment". It was expected a direct relationship between procedural and distributive justice and distributive justice and amenability of the treatment. It was also projected a direct relationship between distributive justice and amenability of the treatment. Results revealed that the adolescent's positive perception of the judicial procedure predicted positively the amenability of both the treatment and the distributive justice system. Perception of the police treatment had an effect on procedural justice. Those findings seem to indicate that if adolescents perceive a fair police treatment and procedure, their acceptance of the treatment and sentence will be more likely. Such an outcome, in turn, could help in their reintegration to society.
\end{abstract}

\section{Keywords}

Procedural Justice, Distributive Justice, Adolescents, Sentence, Amenability Treatment

\section{Introduction}

In recent years, Mexico has experienced a significant increase in crimes perpetrated by adolescents (8 - 17 years

How to cite this paper: Frías-Armenta, M., López-Escobar, A. E., \& Silveira, G. J. (2016). Procedural \& Distributive Justice and Amenability to Psychological Treatment in Juvenile Delinquents. Advances in Applied Sociology, 6, 57-66.

http://dx.doi.org/10.4236/aasoci.2016.62006 
old) and youths (18 - 29 years old). The National Institute of Statistics, Geography and Informatics (INEGI, 2010) reported data from 2004, concerning juvenile delinquents, which indicate that 3776 adolescents were processed in juvenile courts (INEGI, 2010). This institute also revealed that, in 2009, 12,404 minors were kept in detention facilities (INEGI, 2010). In the U.S.A., juveniles committed 13.7\% of the arrests for violent crime and $22.5 \%$ for all property crimes during 2010 (National Center for Injury and Control, 2013).

In December of 2005, the Mexican Constitution was modified to establish due process rights for juveniles and detention as a measure of last resort, only for felonies, and for youngsters older than 14 years old (Constitución Política Mexicana, 2013). The Constitution now mandates that all state laws have to be reformed following this direction. Consequently, public policies and treatment programs have been transformed; nonetheless, juvenile delinquency has increased. It is important to elucidate existing failures in the legal system that aims to decrease juvenile delinquency. In this sense, procedural and distributive justice procedures—as crucial components of such a legal system—have been studied in the field of Psychology-and-Law.

Procedural Justice implies a feeling of impartiality or equity an individual perceives within a judicial procedure (Tyler, 2006). According to equity theory (Tyler, \& Mentovich, 2011) if the perception of the procedure is positive it will produce trust on it and legitimacy of authorities and will decrease subsequent criminal behavior (Tyler \& Blader, 2000). Distributive justice, in turn, is related to an equitable division of benefits in a society and, in a judicial process, refers to the perception of the outcome as fair (Scott, Matland, Michelbach, \& Bornstein, 2001).

The study of the relation between procedural and distributive justice and amenability to treatment could clarify the presence of some flaws in the judicial juvenile system; it could also provide some guidelines in helping to reduce recidivism in juvenile delinquents. There are very few studies, at the international level, assessing the effects of procedural justice on youths. Similarly, there is little research analyzing whether the variables that influence adult perception of procedural justice also affect children and adolescents. Questions about adolescents' significance of procedural and distributive justices arise; also questions about adolescents experiences through the legal system; and how these experiences influence their perception of justice and legality. In Mexico, no research on the influence of procedural and distributive justice systems on juvenile offenders is detected.

\section{Justice}

Justice notion has changed depending on epochs and cultures; yet, the term has always included the idea of equity (Perelman, 1964). From a formal point of view, justice involves a group of precepts established for the regulation of social interaction. It is considered a quality of a social organization, which is related to personal development in a social context: every individual should receive an egalitarian and equitable treatment. Justice is also related to the idea of rectitude inside a social setting (Stammler, 1958), and could be considered as equality of rights among individuals (González de la Vega, 2005). This notion includes universal and individual rights, and considers the concatenation of personal and collective interests to establish a balance and harmony between them and the security of citizens (Pound, 1951). Justice is related to, both, a universal order and a position of human beings within a sphere of personal interrelations.

Approaches to the study of justice in psychology have been discussed in different levels of analysis. Psychology-and-Law has studied procedural and distributive justice systems. Distributive justice refers to the perception of equity from outcomes or sentences in trials or governmental procedures (Tyler, 2006). Procedural justice represents the individual's feelings of impartiality or equity during a judicial procedure. Some researchers have found that procedural justice produces more positive psychological effects than distributive justice does (Tyler \& Blander, 2000).

\subsection{Procedural Justice}

Procedural justice is considered as the establishment of impartial or equitable processes in order to obtain a fair result (Tyler, 2006). The term comes from the legal field and it refers to the perception of control exerted in courts by affected individuals in the resolution of any case (Tyler, 2006: p. 115). Tyler and Bies (1990) argue that individuals ponder how authorities make decisions and treat people when interacting with them. If people judge all these aspects positively they will feel more identified with those authorities. Therefore, individuals will show more loyalty to them and will obey the law more promptly. According to this perspective, procedural 
justice determines people's perception of legitimacy of authorities, to the extent of acceptance of unfavorable results (Jost \& Major, 2001).

In this sense, procedural justice promotes acceptance of and compliance with authorities' decisions. If people are treated with justice, it is more likely that they cooperate and comply with authorities' dispositions and refrain from engaging in criminal behavior. Procedural justice affects people's attitudes; specifically it builds interpersonal trust and trust on authorities, promoting cooperation of individuals with authorities (Lind, 1997). A very important point is that people positively respond to outcomes from legal procedures even when the results are adverse to their interest (Tyler \& Huo, 2002).

Procedural justice (including transparency, impartiality, and respect to human dignity) provides legitimacy to authorities (Tyler, 2003). The perception of legitimacy of authorities could lead to compliance with law (Tyler, 2006). Similarly, procedural justice helps to a voluntary obedience of the law (Maiese, 2004).

Fagan and Tyler (2005) explored the connections between attributions of procedural justice, legal socialization, and adolescents' perceptions of procedural justice in their interactions with legal actors and found that these children's interactions formed their points of view about legitimacy of the law, authorities and institutions. Moreover, a perception of legitimacy of the system was associated with a lower report of juvenile delinquency. These researchers suggest a link between procedural-justice perceptions, the development of conceptions on legal system legitimacy, and delinquency.

Children's experience in the legal system impacts on their perceptions, behaviors, and respect of authorities: their perception of the way they were treated affects children's judgment of the authorities' legitimacy and their further involvement in illegal behavior (Weisz, Wingrove, \& Faith-Slaker, 2007). Legitimacy is central to the dynamic of the socialization process in children. Research in the area has found that people develop points of view about the legitimacy of authorities and that they construct their behavior and derive their interpersonal interactions and experience based on such a process. This process is identified as being part of the adolescents' development (Tyler \& Huo, 2002). Adolescents' interactions and experience with police and other authorities build their perception about other social interactions and influence their notions about law, rules, social agreements and legitimacy of authorities (Tyler, 2006).

\subsection{Distributive Justice}

Distributive justice implies a more equitable distribution of resources (Sangiovanni, 2012), including natural resources and social benefits (Stark, 2010). Rawls (1971) argues that distributive justice is also related to allocation of resources when they are not equally distributed. The perception of distributive justice rests on whether the benefits are material or symbolic (Sangiovanni, 2012), and Otto, Baumert, and Bobocel (2011) establish that it depends on cultural values. Social Resources Theory indicates that not only tangible goods are distributed but also intangible things and fairness perceptions depend on how these benefits are assigned (Baumert \& Schmitt, 2012). A fair society is supposed to guarantee a balance in the benefits that citizens receive (Bou-Habib, 2011).

In a judicial process, sentences represent good news for either part, and this information may be judged as "fair"; yet perceptions of fairness also depend on the process, and the participants (Tyler, 2006). In a criminal process, for example, the offender will tend to perceive the fairness of the sentence different from the victim. For the victim a fair sentence is translated into compensation and for the offender into responsibility. In addition, perceptions are different for diverse age groups: law grants dissimilar rights and obligations for youths and adults (Bou-Habib, 2011). Thus, distributive justice refers to fair outcomes to all parts in a judicial process (Golub, 2009). It is also related to the judgment of impartiality of the results in a decision-making process (Fondacaro, Jackson, \& Luescher, 2002).

Three principles arise in distributive justice: equity, equality and need. Equity denotes proportionality: results are considered fair when outcomes are proportional to inputs. Equality principle is related to dividing the outcomes uniformly between the beneficiaries. If the distribution is based on the needs of the recipients, it approaches the principle of necessity (Fondacaro, Jackson, \& Luescher, 2002). Distributive fairness is linked to cooperation between the individuals of a society (Tyler \& Blader, 2003). In societies, justice is of paramount importance because it affects people disposition to collaborate with others (Tyler, 2009).

Research in adults suggests that their experience with the law contributes to their assessment of legitimacy. A fair treatment allows people to attribute legitimacy to authorities and to build obligations to conform their norms. A just treatment reduces anger feelings that conduce to break the law. In other words, a fair treatment develops 
attachment and bonds to both the law and the social norms (Tyler \& Huo, 2002). The question is whether this situation also applies to youths; one additional question is whether the perceptions of fairness in procedures and sentences combine to influence the acceptance of psychological treatment in young offenders. Therefore, the aim of this research was to investigate the relationship between procedural and distributive justice and the amenability of psychological treatment in juvenile offenders.

\section{Method}

\subsection{Participants}

The instrument was administered to a sample of 92 juvenile offenders; 50 were in a detention facility in the Sonora State of Mexico (Northwestern state) and 42 were receiving external treatment in a community center. The age among participants at the detention facility ranged 14 - 19. Table 1 shows the demographics characteristics of this sample.

Similarly, Table 2 exhibits the demographic characteristics of the 92 adolescents who received treatment in the community center (age ranged 13 through 19).

\subsection{Instrument}

Amenability of the treatment was measured with one scale built expressly for this research. To assess procedural justice we used two scales from Tyler's (2006) study, the ones evaluating perception of judicial procedure and police treatment. They were translated into Spanish and piloted in a Mexican sample. Demographic variables of adolescents, such as age, gender, and education were also assessed, as well as the presence/absence of behavioral and health problems. Finally, demographic data from the parents as age, occupation, marital status, income, and number of children was obtained.

Distributive justice was measured with two questions related to the minors' satisfaction with, both, the received sentence and the judge's resolutions. Participants responded in a scale from 0 (no satisfaction) to 10 (totally satisfactory).

\begin{tabular}{cccc}
\multicolumn{4}{l}{ Table 1. Frequencies of demographic variables. } \\
\hline Variable & Frequency & Total \\
\hline \multirow{2}{*}{ Sex } & Female & 3 & 92 \\
& Male & 89 & \\
Marital status & Single & 90 & 92 \\
& Married & 2 & \\
Work & No & 16 & 92 \\
& Yes & 76 & \\
\hline
\end{tabular}

Table 2. Means and standard deviations of demographic variables.

\begin{tabular}{|c|c|c|c|c|c|}
\hline Variable & $\mathrm{N}$ & Mean & S.D. & Minimum & Maximum \\
\hline Age & 92 & 15 & 1.32 & 13 & 19 \\
\hline Schooling & 92 & 7 & 2 & 1 & 11 \\
\hline Times arrested by the police & 92 & 4.47 & 5.63 & 0 & 30 \\
\hline Age of the father & 92 & 44 & 13 & 29 & 63 \\
\hline Age of the mother & 92 & 39 & 9 & 30 & 56 \\
\hline Monthly income of the father & 92 & 6800 & 4998 & 1500 & 30,000 \\
\hline Monthly income of the mother & 92 & 2592 & 2923 & 0 & 12,000 \\
\hline
\end{tabular}


Perception of police. Eleven items from Tyler's (2006) study constituted this instrument, which measured how much fair or satisfactory the adolescents perceived the management they received from police in a scale from 0 to 10 where 0 means "totally disagree" and 10 "totally agree". The Cronbach's alpha for this scale was 0.78 .

Procedural justice. It was measured with 12 items from Tyler's (2006) instrument. Participants responded using a scale from 0 (perception of injustice) to 10 (perception of justice) in regard to the treatment in the procedure. The reported Cronbach's alpha was 0.85 .

Amenability of the treatment. This scale was elaborated specially for this study, and assessed the responsiveness of adolescents to psychological treatments in a five-point scale (from 0 to 4 ) where 0 means "never" and 4 "always". An alpha of 0.64 was obtained.

\subsection{Procedure}

Permission from the director of the detention facility was granted for the application of the instrument. The adolescents responded to the instrument in a schoolroom inside the detention center, in five groups of 10 participants each. In the community center, the minors individually responded to the instrument before their psychological treatment started. A psychologist provided directions and dissipated their doubts. The researchers explained the objective of the investigation to the participants' parents, guaranteeing the confidentiality of the collected information and assuring them that their children could freely end their participation at any time. Subsequently, the researchers asked participants and their parents to sign a consent form.

\subsection{Data Analysis}

Univariate statistics-frequencies for categorical variables and mean and standard deviation for continuous variables-were obtained, as well as Cronbach's alphas for the scales. In addition, parcels for perception of judicial procedure and satisfaction with the police treatment were computed. Parcels are calculated as the average of randomly selected items for each scale. Parcels are justified in structural modeling when the number of manifest variables or indicators is high, which could make difficult the estimation of relations between variables (Little, Cunningham, Shahar \& Widaman, 2002). Three parcels indicating perception of judicial procedure and satisfaction with police treatment were computed. A structural equation model was specified and tested. Figure 1 shows

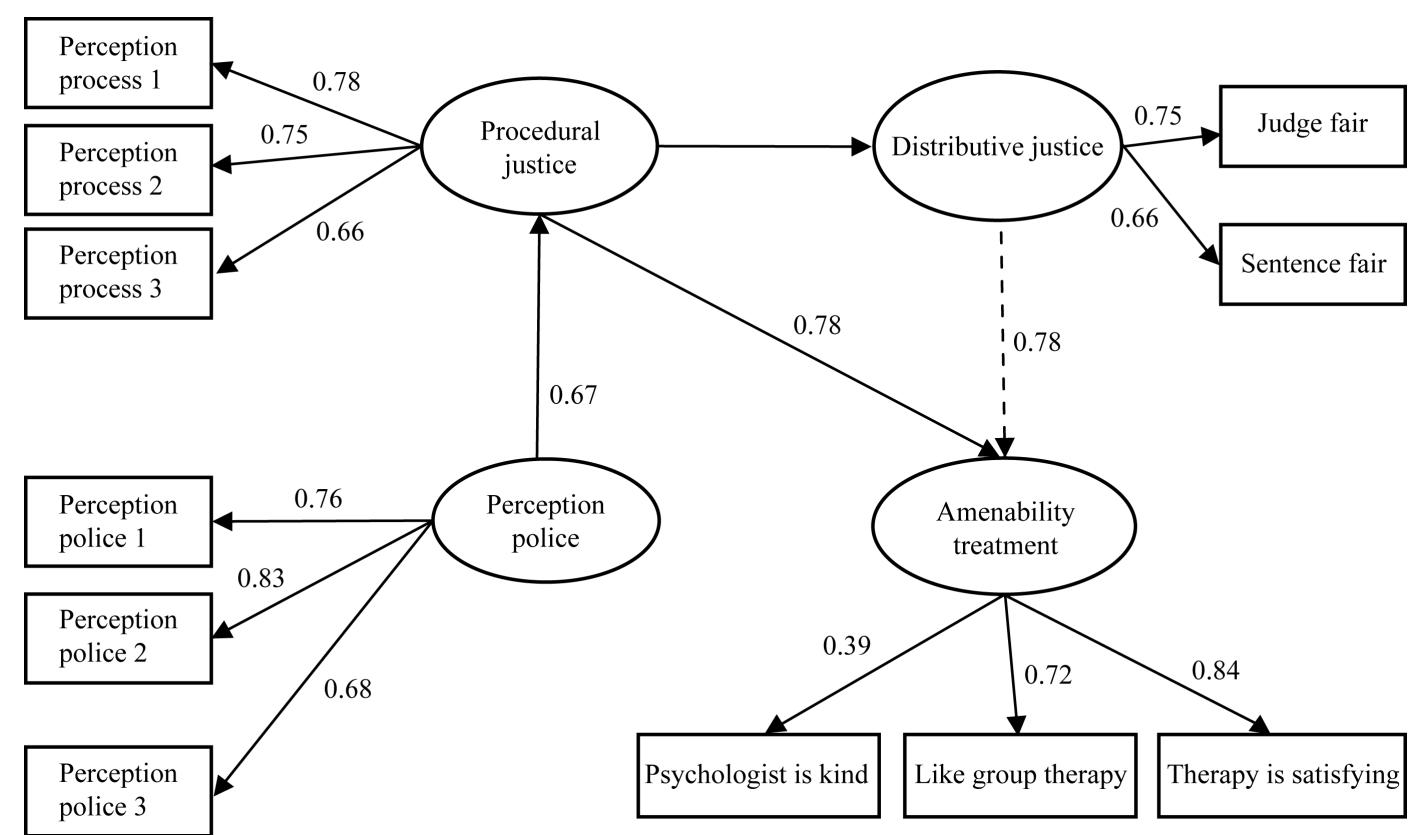

Figure 1. Results of the structural model of procedural justice, distributive justice and amenability to the treatment. All indicated structural coefficients and factor loadings are significant $(p<0.05)$. Goodness of fit: $\mathrm{X}^{2}=49.37$ (39 df.); $p=0.12$; BBNFI $=0.95$; CFI $=0.96$; RMSEA $=0.05$. Model's $\mathrm{R}^{2}=0.35$. 
the relations between the manifest variables and their corresponding factors (i.e., the measurement model). In addition to the "procedural justice" and "perception of police treatment" factors, another latent variable was specified within the structural model: "amenability of the treatment," which had acceptance of "therapy," "psychologist", and "group" as indicators. One more latent variable: "distributive justice," had "sentence conformity" and "perception of decision's justice" as indicators.

Several goodness-of-fit indexes were considered to testing the model's adequacy, including practical and statistical indicators (Ullman, 2006). Goodness-of-fit indicates the appropriateness of the tested theory (i.e., the theoretical relations between variables in the model are supported by the data). Statistical indicators include $\mathrm{X}^{2}$, which should produce a low and non-significant $(p>0.05)$ value. However, $X^{2}$ is sensitive to sample size; therefore, practical indicators should be considered. They are derived from $\mathrm{X}^{2}$ and control for the effect of sample size on significance levels. Practical indicators include the Bentler-Bonnet Normed Fix Index (BBNFI), the Comparative Fix Index (CFI), and the Bentler-Bonnet Non-Normed Fix Index (BBNNFI), which should be higher than 0.90 to indicate goodness-of-fit (Bentler, 2006). One more indicator of this kind is the Root Mean Square Error of Approximation (RMSEA), which should produce a value lower than 0.08 (Browne \& Cudeck, 1993).

\section{Results}

Table 3 shows results of the univariate analyses (means, standard deviations, minimum and maximum scores) and the reliability of the scales. All alphas resulted higher than 0.60 , which could be considered acceptable. The scale "amenability to psychological treatment" produced means from 2.94 to 3.84 (in a rank from 0 to 4), implying that adolescents, in general, positively evaluated the treatment they received from the agency. In the scale "perception of police" 10 out of 11 items produced means from 2.71 to 4.69 (In a rank from 0 to 10) and only one exhibited a mean of 6.55, indicating that adolescents perceived police mostly as dishonest and unfair in treating them. According to the minors' reports, police officers do not inform them about their legal rights during arrests and they do not solve citizen problems properly; therefore, they do not neither feel proud of police officers nor show respect to them. Concerning the "perception of the judicial procedure" scale, its means ranged from 6.10 to 7.73 (in a scale of possible responses from 0 to 10), which indicates that adolescents perceived the process as moderately fair, impartial, and respectful of their basic rights. They also feel satisfaction with the treatment received during the process.

Figure 1 shows the results of the structural model. The measurement model components (i.e., relations between factors and their indicators) are represented by circles (in the case of factors) and by rectangles (in the case of indicators). The factors "perception of police" and "perception of procedural justice" emerged coherently from the inter-relations between their indicators. High and significant $(p<0.05)$ factor loadings confirmed the construct validity of the four assessed latent variables. The factor loadings for procedural justice were $0.78,0.75$ and 0.66 for the first, second and third parcels, respectively. In the case of the "perception of the police" factor, the loadings were $0.76,0.83$ and 0.66 , corresponding to the first, second and third parcels. For the "amenability of the treatment" construct, the factor loading for "I feel good with the psychologist" was $0.39,0.72$ for "I like to assist to therapy" and 0.84 for "I feel that therapy is helping me". For the "distributive justice" factor the loadings were 0.75 for "judges were not fair", and 0.66 for "the sentence was not just".

The structural model indicates that the perception of police ( $\mathrm{SC}=0.67)$ affects the perception of procedural justice, which in turn influences the amenability of the psychological treatment $(\mathrm{SC}=0.42)$. The perception of procedural justice also has an effect on adolescents' perception of distributive justice $(\mathrm{SC}=0.77)$ yet, this latter perception does not affect the amenability to the treatment, contrarily to what we had anticipated.

The goodness of fit indicators of the model resulted in $\mathrm{X}^{2}=49.37$ (39 df; $p=0.12$ ), while the practical indicators produced a BBNFI $=0.95$, a CFI $=0.96$, and a RMSEA value $=0.05$. These values suggest that the model fits the data well. The $\mathrm{R}^{2}$ of the model was 0.35 , indicating that the model predicted $35 \%$ of the variance in amenability of the treatment.

\section{Discussion}

Results of our model show that the juvenile delinquents' perception of the treatment they received from the police, when they were arrested, affects the way they perceive procedural justice. This latter perception, in turn, predict additional perceptions regarding distributive justice and amenability to the psychological treatment they 
Table 3. Alphas of the scales and mean and standard deviation of the items.

\begin{tabular}{|c|c|c|c|c|c|c|}
\hline Scale/Items & $\mathrm{N}$ & M & S.D. & Min & Max & Alpha \\
\hline AMENABILITY TO THE TREATMENT & & & & & & 0.64 \\
\hline Psychologist understands what I try to say. & 90 & 3.64 & 0.90 & 0 & 4 & \\
\hline I feel good with psychologist. & 90 & 3.84 & 0.65 & 0 & 4 & \\
\hline I feel the psychologist helps me. & 90 & 3.64 & 0.81 & 0 & 4 & \\
\hline I like to attend groups of therapy. & 86 & 2.94 & 1.40 & 0 & 4 & \\
\hline I have very good time in the groups. & 86 & 3.04 & 1.42 & 0 & 4 & \\
\hline PERCEPTION OF THE POLICE TREATMENT & & & & & & 0.78 \\
\hline I feel respect to the police. & 92 & 4.69 & 3.75 & 0 & 10 & \\
\hline Policemen are honest. & 92 & 2.71 & 3.22 & 0 & 10 & \\
\hline I feel proud of the police. & 92 & 3.25 & 3.30 & 0 & 10 & \\
\hline Police explained me my rights when I have been arrested. & 92 & 2.84 & 3.82 & 0 & 10 & \\
\hline How you feel police treatment when you have problems on the street. & 92 & 3.40 & 3.41 & 0 & 10 & \\
\hline How fair do you feel the results were? & 92 & 4.42 & 3.62 & 0 & 10 & \\
\hline $\begin{array}{l}\text { How satisfied do you feel with policemen when they } \\
\text { solve problems in the city and help people? }\end{array}$ & 92 & 6.55 & 3.34 & 0 & 10 & \\
\hline Police treat fairly all citizens. & 92 & 3.73 & 3.57 & 0 & 10 & \\
\hline People like you receive the same treatment police gives everybody. & 92 & 4.19 & 3.16 & 0 & 10 & \\
\hline $\begin{array}{l}\text { When you have been arrested police managed } \\
\text { the situation satisfactorily. }\end{array}$ & 92 & 4.46 & 3.87 & 0 & 10 & \\
\hline PROCEDURAL JUSTICE. & & & & & & 0.86 \\
\hline How satisfied do you feel with judge treatment? & 92 & 7.25 & 3.53 & 0 & 10 & \\
\hline Do you think that judges are just? & 92 & 7.22 & 3.05 & 0 & 10 & \\
\hline Do you think judges resolve all cases with justice? & 92 & 7.54 & 2.90 & 0 & 10 & \\
\hline Judges try all fairly. & 92 & 5.93 & 3.43 & 0 & 10 & \\
\hline Juveniles received the same treatment than adults. & 92 & 5.79 & 3.39 & 0 & 10 & \\
\hline Judges guarantee to all a fair trial. & 92 & 7.38 & 3.35 & 0 & 10 & \\
\hline Fundamental rights of citizens are well protected. & 92 & 7.73 & 2.97 & 0 & 10 & \\
\hline Judge decisions are always just. & 92 & 6.36 & 3.60 & 0 & 10 & \\
\hline
\end{tabular}

are receiving. Yet, amenability to treatment was no affected by their perception of distributive justice. These findings suggest that if adolescents feel that their process was fair, they will be more willing to accept the treatment and judicial sentence.

Juvenile delinquents in our study pointed at police officers as dishonest, unfair and violent. However, they accept and agree to receive psychological treatment, and seem to like attending such a treatment, which they refer to as "very comfortable" and "helpful". The perception of a fair procedural justice was not very pronounced among the interviewed adolescents, yet this justice was perceived better than the treatment received from police officers. Perception of procedural justice is important, according to our data, because it influences the amenability of the treatment, a key factor in the reinsertion of juvenile delinquents to society. Our findings suggest that if they feel that judges did not give a respectful treatment during the judicial procedure (including impartiality, equity, and respect to their dignity and rights) they will not exhibit willingness to cooperate in the psychological 
treatment. Adolescents would also not be attracted to attend therapeutic sessions and probably would not feel improvements from the psychological treatment. Moreover, if our data were correct, they would be revealing that a favorable perception of procedural justice would lead adolescents to consider their sentence as a fair one, even if they have received negative results. This consideration could be also helpful in looking at the treatment as a source of social reinsertion.

Fagan and Tyler (2005) suggest a relationship between perception of procedural justice and juvenile delinquency. Their results showed that if adolescents perceive the judicial process as a fair one their amenability to the treatment and acceptance of the sentence are more likely to occur, and this could reduce recidivism. A fair treatment from authorities could increase the perception of their legitimacy; it also helps in creating more loyalty to them and in influencing law compliance. That means that a fair process could help in developing adolescents' adherence to the law, because their perception of the treatment in the judicial system conceives it as a fair process (Tyler \& Huo, 2002).

Distributive justice showed no effect on amenability to the treatment. This result supports Tyler and Blander's (2000) argument stating that procedural justice produces more positive psychological effects than distributive justice does. That means that if citizens perceive fairness and impartiality in legal processes such perception will produce more trust on results than the resulting sentence. The outcome is less important when the process has not been clear. Trust on the process impact not only on acceptance of the sentence and the treatment, and likely on the change of adolescents' attitude towards the legal system and social norms.

These results can lead to some recommendations: first, it is important to consider the role of police officers in adolescents' acceptance of the treatment and subsequent recidivism. Therefore, police officers should receive special training for the treatment of juvenile offenders; in addition, they should be knowledgeable of children rights, development and needs. The Convention on the Rights of the Child requires this training and knowledge, and all states should fulfill this legislation. Another recommendation is to replace police officers; using social educators instead, as Spain does in organizing its juvenile judicial system. Concerning procedural justice, judges' respectful attitudes and behaviors concerning children rights should be promoted; every process should include transparency, impartiality, and respect to children dignity. A fair participation of children during the process is also important. This study has implications in Juvenal justice, creators of public policies and laws should recognize that the participation of juveniles offenders on the process influence law compliance and allow them contribute.

Some limitations of this study might limit the generalizability of our findings: the reduced size of the sample is one of them. In the community facility, it was necessary to set appointments to adolescents, some adolescents do not attend appointments, and sometimes it is very difficult to set another one. Yet, we consider that these findings are revealing valid, reliably and important information to utilize in the treatment of juvenile delinquents.

\section{Acknowledgements}

CONACYT México, funding number 179269, supported this research.

\section{References}

Baumert, A., \& Schmitt, M. (2012). Some Hypotheses on Cross-Cultural Differences in the Impact of Resource Type on the Preferred Principle of Distributive Justice. In K. Törnblom \& A. Kazemi (Eds.), Handbook of Social Resource Theory (pp. 273-281). New York: Springer. http://dx.doi.org/10.1007/978-1-4614-4175-5 17

Bentler, P. M. (2006). EQS 6, Structural Equations Program Manual. Encino, CA: Multivariate Software Inc. http://www.econ.upf.edu/ satorra/CourseSEMVienna2010/EQSManual.pdf

Bou-Habib, P. (2011). Distributive Justice, Dignity, and the Lifetime View. Social Theory and Practice, 37, $285-308$. http://www.jstor.org/stable/23558544

http://dx.doi.org/10.5840/soctheorpract201137216

Browne, M. W., \& Cudeck, R. (1993). Alternative Ways of Assessing Model Fit. In K. A. Bollen, \& J. S. Long (Eds.), Testing Structural Equation Models (pp. 136-162). Thousand Oaks, CA: Sage.

Constitución Política de los Estados Unidos Mexicanos (Political Constitution of the Mexican United States) (2013). Reforma publicada en el Diario Oficial de la Federación el 12 de diciembre de 2005 (Published in the Oficial Journal of Federationon December 12 of 2015).

http://www.diputados.gob.mx/LeyesBiblio/ref/dof/CPEUM_ref_165_12dic05_ima.pdf 
Fagan, J., \& Tyler, T. R. (2005). Legal Socialization of Children and Adolescents. Social Justice Research, 18, $217-241$. http://dx.doi.org/10.1007/s11211-005-6823-3

Fondacaro, M. R., Jackson, S. L., \& Luescher, J. (2002). Toward the Assessment of Procedural and Distributive Justice in Resolving Family Disputes. Social Justice Research, 15, 341-370. http://dx.doi.org/10.1023/A:1021219124369

Golub, S. (2009). Make Justice the Organizing Principle of the Rule of Law Field. Hague Journal on the Rule of Law, 1, 6166. http://dx.doi.org/10.1017/S187640450900061X

González de la Vega, R. (2005). Justicia e ideología (Justice and ideology.). México City: Universidad Autónoma de México (AutonomousUniversity of Mexico). Instituto de Investigaciones Jurídicas (Legal Research Center).

http://biblio.juridicas.unam.mx/libros/libro.htm?l=1554

Instituto Nacional de Estadística, Geografía e Informática (MexicanInstitute of statistics, Geography and informatics). (INEGI). Encuesta Nacional de Gobierno de México (NationalSurvey of MexicanGovernment). (2010). www.inegi.org.mx

Instituto Nacional de Estadística, Geografía e Informática (Mexican Institute of statistics, Geography and Informatics) (2010). Anuario Estadístico del Estado de Sonora (Statistics Yearbook of Sonora State). Mexico City: INEGI.

Jost, J. T., \& Major, B. (2001). The Psychology of Legitimacy: Emerging Perspectives on Ideology, Justice and Intergroup Relations (2nd ed.). London: Cambridge University Press.

Lind, E. A. (1997). Litigation and Claiming in Organizations: Antisocial Behavior or Quest for Justice? In R. A. Giacalone, \& J. Greenberg (Eds.), Antisocial Behavior in Organizations (pp. 150-171). Thousand Oaks, CA: Sage.

Little, T., Cunningham, W., Shahar, G., \& Widaman, K. (2002). To Parcel or Not Parcel: Exploring the Question, Weighing the Merits. Structural Equation Modeling: A Multidisciplinary Journal, 9, 151-173. http://dx.doi.org/10.1207/S15328007SEM0902_1

Maiese, M. (2004). Procedural Justice: Beyond Intractability. In G. Burgess, \& H. Burgess (Eds.), Conflict Information Consortium. Boulder, CO: University of Colorado. http://www.beyondintractability.org/bi-essay/procedural-justice

National Center for Injury and Control (2013). http://www.cdc.gov/ViolencePrevention/pdf/YV-DataSheet-a.pdf.

Otto, K., Baumert, A., \& Bobocel, D. R. (2011). Cross-Cultural Preferences for Distributive Justice Principles: Resource Type and Uncertainty Management. Social Justice Research, 24, 255-277. http://dx.doi.org/10.1007/s11211-011-0135-6

Perelman, C. (1964). De la Justicia. México D. F.: Universidad Autónoma de México, Instituto de Investigaciones Jurídicas. http://biblio.juridicas.unam.mx/libros/1/453/1.pdf

Pound, R. (1951). The Need of a Sociological Jurisprudence. Justice According to Law. New Haven, CT: Yale University Press.

Rawls, J. (1971). A Theory of Justice. Cambridge, CA: Harvard University Press.

Sangiovanni, A. (2012). The Irrelevance of Coercion, Imposition, and Framing to Distributive Justice. Philosophy \& Public Affairs, 40, 79-110. http://dx.doi.org/10.1111/j.1088-4963.2012.01213.x

Scott, J. T., Matland, R. E., Michelbach, P. A., \& Bornstein, B. H. (2001). Just Deserts: An Experimental Study of Distributive Justice Norms. American Journal of Political Science, 45, 749-767. http://dx.doi.org/10.2307/2669322

Stammler, R. (1958). La esencia del derecho y la ciencia del derecho. Madrid, Es: Espasa—Calpe.

Stark, B. (2010). Jam Tomorrow: Distributive Justice and the Limits of International Economic Law. Boston College Third World Law Journal, 30, 3-34.

https://www.bc.edu/content/dam/files/schools/law/lawreviews/journals/bctwj/30_1/twlj_30_1_web.pdf

Tyler, T. R. (2003). Procedural Justice, Legitimacy, and the Effective Rule of Law. In M. H. Tonry (Ed.), Crime and Justice: A Review of Research (Vol. 30, pp. 431-505). Chicago and London: University of Chicago Press. http://dx.doi.org/10.1086/652233

Tyler, T. R. (2006). Perception of Adolescents about the Judicial Procedure and Treatment in Detention and Their Effect on Social Rehabilitation. Princeton, NJ: Princeton University Press.

Tyler, T. R. (2009). Procedural Justice, Identity and Deference to the Law: What Shapes Rule-Following in a Period of Transition? Australian Journal of Psychology, 61, 32-39. http://dx.doi.org/10.1080/00049530802607639

Tyler, T. R., \& Bies, R. J. (1990). Beyond Formal Procedures: The Interpersonal Context of Procedural Justice. In J. Carroll (Ed.), Applied Social Psychology and Organizational Settings (pp. 77-98). Hillsdale, NJ: L. Erlbaum Associates.

Tyler, T. R., \& Blader, S. L. (2000). Cooperation in Groups: Procedural Justice, Social Identity, and Behavioral Engagement. Philadelphia, PA: Psychology Press.

Tyler, T. R., \& Blader, S. L. (2003). The Group Engagement Model: Procedural Justice, Social Identity, and Cooperative Behavior. Personality and Social Psychology Review, 7, 349-361. http://dx.doi.org/10.1207/S15327957PSPR0704_07 
Tyler, T. R., \& Huo, Y. J. (2002). Trust in the Law: Encouraging Public Cooperation with the Police and Courts. New York: Russell Sage Foundation.

Tyler, T. R., \& Mentovich, A. (2011). Mechanisms of Legal Effect: Theories of Procedural Justice. A Methods Monograph. New York: Robert Wood Johnson Foundation.

Ullman, J. B. (2006). Structural Equation Modeling: Reviewing the Basics and Moving Forward. Journal of Personality Assessment, 87, 35-50. http://dx.doi.org/10.1207/s15327752jpa8701_03

Weisz, V., Wingrove, T., \& Faith-Slaker, A. (2007). Children and Procedural Justice: Court Review. The Journal of the American Judges Association, 44, 36-42. http://digitalcommons.unl.edu/ajacourtreview/216 